\title{
Multilocus Sequence Typing of Pseudomonas syringae Sensu Lato Confirms Previously Described Genomospecies and Permits Rapid Identification of $P$. syringae pv. coriandricola and P. syringae pv. apii Causing Bacterial Leaf Spot on Parsley
}

\author{
Carolee T. Bull, Christopher R. Clarke, Rongman Cai, Boris A. Vinatzer, Teresa M. Jardini, and Steven T. Koike
}

First and fifth authors: United States Department of Agriculture-Agricultural Research Service, 1636 E. Alisal St., Salinas, CA 93905; second, third, and fourth authors: Plant Pathology, Physiology, and Weed Science Department, Latham Hall, Virginia Tech, Blacksburg 24061; and sixth author: University of California Cooperative Extension, Salinas 93901.

Accepted for publication 7 February 2011.

\begin{abstract}
Bull, C. T., Clarke, C. R., Cai, R., Vinatzer, B. A., Jardini, T. M., and Koike, S. T. 2011. Multilocus sequence typing of Pseudomonas syringae sensu lato confirms previously described genomospecies and permits rapid identification of $P$. syringae pv. coriandricola and $P$. syringae pv. apii causing bacterial leaf spot on parsley. Phytopathology 101:847-858.

Since 2002, severe leaf spotting on parsley (Petroselinum crispum) has occurred in Monterey County, CA. Either of two different pathovars of Pseudomonas syringae sensu lato were isolated from diseased leaves from eight distinct outbreaks and once from the same outbreak. Fragment analysis of DNA amplified between repetitive sequence polymerase chain reaction; 16S rDNA sequence analysis; and biochemical, physiological, and host range tests identified the pathogens as Pseudomonas syringae pv. apii and $P$. syringae pv. coriandricola. Koch's postulates were com-

and coriander or cilantro. In a multilocus sequence typing (MLST) approach, four housekeeping gene fragments were sequenced from 10 strains isolated from parsley and 56 pathotype strains of $P$. syringae. Allele sequences were uploaded to the Plant-Associated Microbes Database and a phylogenetic tree was built based on concatenated sequences. Tree topology directly corresponded to $P$. syringae genomospecies and $P$. syringae pv. apii was allocated appropriately to genomospecies 3 . This is the first demonstration that MLST can accurately allocate new pathogens directly to $P$. syringae sensu lato genomospecies. According to MLST, $P$. syringae pv. coriandricola is a member of genomospecies $9, P$. cannabina. In a blind test, both $P$. syringae pv. coriandricola and $P$. syringae pv. apii isolates from parsley were correctly identified to pathovar. In both cases, MLST described diversity within each pathovar that was previously unknown.
\end{abstract} pleted for the isolates from parsley, and host range tests with parsley isolates and pathotype strains demonstrated that $P$. syringae pv. apii and $P$. syringae pv. coriandricola cause leaf spot diseases on parsley, celery,
Additional keywords: Apiaceae, Apium graveolens, Coriandrum sativum, DNA/DNA hybridization, species concept.
The taxonomy of Pseudomonas syringae sensu lato is complicated by the heterogeneous nature of the species $(12,21,23,51,60)$. The species is delineated into pathovars (an infrasubspecific designation for phytopathogenically distinct members of a species) derived from the consolidation of related nomenspecies as part of the new start to bacterial taxonomy in $1980(10,19$, $21,33,60)$. The taxonomy of $P$. syringae is further complicated because individual nomenspecies from which the pathovars were derived were proposed based on relatively few characters and limited host range testing $(55,60)$. Although it was anticipated that additional data would eventually elevate pathovars of $P$. syringae to species, the data of Gardan et al. (21) indicate that genetic species within $P$. syringae sensu lato are also heterogeneous, consisting of multiple pathovars with variable taxonomic characteristics, making them difficult to distinguish. Only two of the nine genomospecies were proposed as species because the others could not be distinguished from one another. Genomospecies 9 was elevated to $P$. cannabina based on relatively few strains, and

Corresponding author: C. T. Bull; E-mail address: Carolee.Bull@ars.usda.gov

* The $\boldsymbol{e}$-Xtra logo stands for "electronic extra" and indicates that the online version contains three supplemental tables and one supplemental figure.

doi:10.1094/PHYTO-11-10-0318

This article is in the public domain and not copyrightable. It may be freely reprinted with customary crediting of the source. The American Phytopathological Society, 2011 this limited diversity may have allowed this taxon to be more easily distinguished from other genomospecies using classical techniques. Strains representing a wider range of diversity have recently been allocated to this species, requiring that the species be emended (12).

The complicated classification of $P$. syringae sensu lato results in ongoing difficulty in allocating new organisms to genomospecies and pathovars within the species. Currently, novel strains of $P$. syringae can be classified to pathovar only after tedious host range testing. However, there are no standards for the number or type of hosts that should be tested and what pathovars of $P$. syringae should be used as controls in comparisons. In some cases, manuscripts are published in which comparisons are not even made to the pathotype strains. The allocation of strains to genomospecies is also impractical because it requires repeating many of the paired DNA/DNA hybridization (DDH) experiments conducted by Gardan et al. (21) with the isolates from the novel disease.

Although phenotypic characterization and completing Koch's postulates is relatively straightforward, the classical methods are time consuming. Additionally, phenotypic characterization requires comparisons with the pathotype strains, including host range testing, in addition to laboratory experiments. Analysis of fragments amplified using the polymerase chain reaction primed by repetitive extragenic sequences (rep-PCR) (48) can be used to compare genotypes of unknowns to pathotype genotypes to which they may be related. This approach still requires importation of a variety of pathotypes for comparisons. 
Sequence-based identification using public databases is portable, data are additive, and it does not require importation of strains for initial comparisons $(39,60)$. Multilocus sequence typing (MLST) (38) is a molecular typing method that is based on comparing sequence fragments of multiple housekeeping genes (i.e., genes that code for proteins that perform basic metabolic functions, are present in most bacteria, and are under purifying selection), designating a "sequence type" (ST) for each strain based on which alleles are present, and phylogenetic analysis using the concatenated DNA sequences of the analyzed loci or allele assignments.

The Plant-Associated Microbes Database (PAMDB) (1) is a database accessible over the internet (www.pamdb.org) that was specifically designed for MLST of plant pathogens. PAMDB makes it possible for users to (i) compare their unknown isolates to strains deposited in PAMDB and (ii) add MLST results of their isolates to expand PAMDB. Recently, we used MLST and PAMDB to confirm the position of $P$. cannabina pv. alisalensis (formerly $P$. syringae pv. alisalensis) in P. cannabina (genomospecies 9) and suggested that MLST could be used to allocate strains from new diseases to genomospecies and pathovars (12). In this article, we present data confirming this hypothesis.

Since 2002, a severe leaf spot disease on parsley has occurred throughout central coastal California and, in particular, in Monterey County. Members of $P$. syringae sensu lato have been consistently isolated from diseased parsley leaves. Two $P$. syringae pathovars have been reported to cause disease on members of the family Apiaceae $(25,59)$. Northern bacterial blight of celery (Apium graveolens L. var. dulce (Mill.) Pers.), caused by $P$. syringae pv. apii, was first described from epidemics on celery in New York by Jagger in 1921 (25). In addition to reports from the United States and worldwide $(6,20)$, since 1989, P. syringae pv. apii has continued to cause northern bacterial blight of celery in central coastal California (C. T. Bull and S. T. Koike, unpublished) $(27,28,30,35)$. Bacterial leaf spot of coriander (Coriandrum sativum) is caused by $P$. syringae pv. coriandricola (59). Although the formal proposal for the pathovar $P$. syringae pv. coriandricola occurred in 1996, the disease was reported in California, on both coriander grown for seed as a spice or cilantro grown for fresh foliage in 1991 (17), and throughout the world $(14,15,45,58)$. These two pathogens cause very similar bacterial leaf spotting diseases on members of the family Apiaceae but neither has been reported on parsley. Although the diseases they cause are similar, it is not clear whether the organisms belong to the same or different genomospecies. P. syringae pv. apii is a member of genomospecies 3 and is related to $P$. syringae pv. tomato (21). The genomospecies to which $P$. syringae $\mathrm{pv}$. coriandricola belongs remains to be determined.

This research was designed to evaluate the ability of MLST to allocate unknown pathogens from new diseases to well-established genomospecies and pathovars within P. syringae sensu lato. In this article, we report the sequencing of four loci from the pathotype strains of the majority of pathovars of $P$. syringae and addition of the sequences to PAMDB. Identifications of unknown pathogens from a novel parsley disease based on classical methods and demonstration of Koch's postulates as well as pathogenicity evaluations were made at the United States Department of Agriculture-Agricultural Research Service in Salinas, CA. The DNA from pathotypes of $P$. syringae and coded unknown strains were sent to Virginia Tech in Blacksburg, VA for MLST identification. No information about the host or pathogens was provided to the co-authors at Virginia Tech prior to their identification by MLST. We then used the data from PAMDB to confirm the identification of the pathovars. Because there are no peer-reviewed publications describing $P$. syringae causing disease on parsley, this represented a prime opportunity to test the ability of MLST and the data in PAMDB to correctly identify pathogens from novel diseases and allocate them to the correct genomo- species. This research combines phylogenetic analysis of DNA sequences with the analysis of ecologically important phenotypes within the current taxonomic framework of $P$. syringae sensu lato, thus providing criteria for identification of unknowns based on an ecological-evolutionary species concept (60).

\section{MATERIALS AND METHODS}

Microorganisms and media. The bacteria used in these studies are listed in Tables 1 and 2. The pathotype strains of $P$. syringae and $P$. cannabina were obtained from the Collection Française de Bactéries Phytopathogènes (CFBP); the International Collection of Micro-organisms from Plants, Landcare Research; the Laboratorium voor Microbiologie University of Gent; or the National Collection of Plant Pathogenic Bacteria (NCPPB). The bacteria were stored at $-80^{\circ} \mathrm{C}$ in a solution of $50 \%$ glycerol and 50\% nutrient broth (Difco Laboratories, Detroit) and were routinely cultured on King's medium B agar (KMB) (26).

Isolation of the causal agent. Between 2003 and 2009, nine parsley samples from separate disease outbreaks were obtained by the University of California Cooperative Extension through the plant disease clinic (Table 2). Symptomatic leaves were surface sterilized with $0.5 \%$ sodium hypochlorite for $1 \mathrm{~min}$ followed by rinsing in sterile distilled water three times. Small (3-by-3-mm) sections of tissue were excised aseptically from leaf spot margins and macerated in $40 \mu \mathrm{l}$ of sterile distilled water. The resulting suspensions or a dilution were streaked onto sucrose peptone agar (13) and incubated at 24 to $26^{\circ} \mathrm{C}$. After 3 to 5 days, single colonies were purified and stored.

16S rDNA sequence analysis. For amplification of the $16 \mathrm{~S}$ rDNA genes, genomic DNA was isolated using NucleoSpin Tissue kits (Macherey-Nagel, Deer Park, NY). An MJ Research DNA-Engine thermocycler (Bio-Rad Laboratories, Hercules, CA) with a heated lid in the "calculated" mode was used for all PCRs. Amplicons for the 16S rDNA sequences were generated using universal primers $27 \mathrm{~F}$ and 1492R (31) using published reaction conditions (62). After visually checking for amplification by gel electrophoresis, amplicons were purified using a NucleoSpin Extract II PCR Cleanup kit (Macherey-Nagel). Amplicons were sequenced directly by an outside vendor (McLab, South San Francisco, CA). Geneious software (http://www.geneious.com) was used to align sequences from forward and reverse strands and generate consensus sequences, and a basic local alignment search tool (BLAST) (2) was used to compare sequences from unknowns with sequences in public databases.

Genotypic characterization using rep-PCR. To determine the genetic variability among isolates from the nine bacterial leaf spot outbreaks, all 70 isolates were compared using rep-PCR. Isolates were first compared within an outbreak and then representative isolates from each outbreak were compared with each other. Representative parsley isolates were then compared with the pathotype strains of $P$. syringae pv. apii and $P$. syringae pv. coriandricola pathotypes in genomospecies 3 and 9 (P. cannabina) and historical strains of $P$. syringae pv. apii and $P$. syringae pv. coriandricola isolated from diseased celery and cilantro grown in the Salinas Valley, CA. PCR amplification of repetitive sequences was accomplished with the BOXA1R primer (5'-CTA-CGGCAA-GGC-GAC-GCT-GAC-G-3'), synthesized by Integrated DNA Technologies, Inc. (Coralville, IA), that is designed to prime DNA synthesis from the BOXA subunit of the BOX element $(16,48)$. Purified DNA was amplified and DNA fragments were separated by agarose gel electrophoresis in $1.5 \%$ agarose gels in $0.5 \times$ Tris-acetate-EDTA buffer. Gels were stained with GelRed and bands were visualized on a UV transilluminator. DNA fragment-banding patterns generated from pathotype strains and parsley isolates were compared visually and the degree of relatedness among the strains estimated using BioNumerics software (v. 2.5; Applied Maths, Austin, TX), which analyzes 
degree of similarity among banding patterns and generates dendrograms to visualize the results. Based on the rep-PCR results, further evaluations were conducted on a limited number of isolates representing the genetic diversity of parsley isolates.

Phenotypic characterization of pathogens. In addition to being compared by rep-PCR, all 70 parsley isolates were evaluated for fluorescence on $\mathrm{KMB}$ and were tested, using published methods $(12,34,52)$, for gram character (with the $\mathrm{KOH}$ test); levan production, oxidase reaction, potato rot ability, arginine dihydrolase production, and tobacco hypersensitivity (LOPAT); and ice-nucleating ability. Additionally, carbon source utilization was evaluated for at least one representative isolate from each of the nine parsley leaf spot outbreaks. The API $50 \mathrm{CH}$ kit (BioMerieux, Marcy l'Etoile, France) was used to determine the ability of the strains and isolates to utilize 50 carbon sources. AUX medium (32) was used to inoculate the cupules of the strips according to the manufacturer's recommendations. The strips were then incubated at $28^{\circ} \mathrm{C}$ and growth was recorded after 1 and 2 days for each cupule.

Fatty acid methyl esters. Representative isolates from the nine parsley outbreaks and controls were grown and fatty acids were methyl esterified and extracted using a previously published method (12). Fatty acid methyl esters were analyzed with the Sherlock Microbial Identification System (version 6.1; MIDI Inc., Newark, DE) using an automated GC 6890 Hewlett-Packard gas chromatograph fitted with a 25-by-0.2-mm phenyl methyl silicone-fused silica capillary column, an HP 7683 automatic sampler, and Agilent ChemStation Software (version B.03.02). The mean and standard deviation of the area for each named peak from three independent replications was reported as a percentage of the total area of all peaks in the chromatogram, not including the solvent peak.

Toxin production genes. To determine whether the biosynthesis genes for bacterial toxins were present, primers designed to amplify biosynthesis genes for coronatine $(c f l)(4,66)$, syringomycin, (syrB) (53), tagitioxin (TAGTOX-10) (29), or tabtoxin (tblA) (37) were used to amplify fragments using published methods. The pathogens from parsley were evaluated along with pathotype strains of $P$. syringae pv. maculicola, $P$. syringae $\mathrm{pv}$. syringae, $P$. syringae pv. tagetis, and $P$. syrignae pv. tabaci, which were used as positive and negative controls.

Pathogenicity and host range evaluations. At least one representative parsley isolate from each of the nine disease outbreaks was evaluated in three independent experiments evaluating pathogenicity on parsley ('Italian'). Pathogenicity of a subset of the isolates that were shown to be pathogenic on parsley was also evaluated on celery ('Conquistador') and coriander or cilantro ('Spice' or 'Santo') in two independent experiments. Plants inoculated with the pathotype strain of $P$. syringae pv. syringae served as a negative control; positive controls were inoculated with the pathotype strains of $P$. syringae pv. apii and $P$. syringae pv. coriandricola.

Inoculum was prepared from lawns of bacteria grown on nutrient agar for $48 \mathrm{~h}$ at $27^{\circ} \mathrm{C}$. Cultures were suspended in phosphate buffer (0.01 M, pH 7.0) and the resulting bacterial suspensions were adjusted with a spectrophotometer to an optical density of 0.10 at a wavelength of $600 \mathrm{~nm}$, corresponding to $\approx 1 \times$ $10^{8} \mathrm{CFU} / \mathrm{ml}$ as determined by dilution plating. Carborundum $(\approx 0.04 \mathrm{~g})$ was added to $300 \mathrm{ml}$ of the suspensions and a cotton swab was used to spread the suspension onto fully expanded true leaves of 15-week-old parsley, or bacteria were spray inoculated until runoff. The inoculum was allowed to dry on the plants for $1 \mathrm{~h}$, after which plants were placed in a humid chamber for $48 \mathrm{~h}$ and then maintained in a greenhouse at 20 to $25^{\circ} \mathrm{C}$ and evaluated for symptoms after 14 to 21 days.

For all pathogenicity tests, symptomatic tissue was surface sterilized, excised, and macerated following the procedures used in the original isolations. Tissue was isolated from random loca-
TABLE 1. Summary of genetic data for type and pathotype strains of Pseudomonas syringae, P. cannabina, and related pathogens

\begin{tabular}{|c|c|c|c|}
\hline \multirow[b]{2}{*}{ Type, pathotype } & \multirow[b]{2}{*}{ Designation $^{\mathrm{a}}$} & \multicolumn{2}{|c|}{ Genomospecies as determined by } \\
\hline & & $(12,21)$ & This study \\
\hline \multicolumn{4}{|l|}{ P. syringae } \\
\hline pv. aceris & LMG $2106^{\mathrm{PT}}$ & 1 & $\cdots$ \\
\hline pv. actinidiae & NCPPB $3739^{\mathrm{PT}}$ & ND & 3 \\
\hline pv. aesculi & NCPPB $3681^{\mathrm{PT}}$ & 2 & $\ldots$ \\
\hline pv. antirrhini & CFBP $1620^{\mathrm{PT}}$ & 3 & $\ldots$ \\
\hline pv. apii & LMG $2132^{\mathrm{PT}}$ & 3 & $\ldots$ \\
\hline pv. apii & NCPPB $1626^{\mathrm{PT}}$ & 3 & $\ldots$ \\
\hline pv. aptata & CFBP $1617^{\text {PT }}$ & 1 & $\ldots$ \\
\hline pv. atrofaciens & LMG $5095^{\mathrm{PT}}$ & 1 & $\ldots$ \\
\hline pv. atropurpurea & NCPPB $2397^{\mathrm{PT}}$ & 4 & $\ldots$ \\
\hline pv. berberidis & CFBP $1727^{\mathrm{PT}}$ & 3 & $\ldots$ \\
\hline pv. broussonetiae & ICMP $13650^{\mathrm{PT}}$ & ND & 1 \\
\hline pv. cerasicola & CFBP $6109^{\mathrm{PT}}$ & ND & 2 \\
\hline pv. ciccaronei & LMG $5541^{\mathrm{PT}}$ & 2 & $\ldots$ \\
\hline pv. coriandricola & ICMP $12471^{\mathrm{PT}}$ & ND & 9 \\
\hline pv. coronafaciens & NCPPB $600^{\mathrm{PT}}$ & 4 & $\ldots$ \\
\hline pv. coryli & NCPPB $4273^{\mathrm{PT}}$ & ND & 1 \\
\hline pv. cunninghamiae & ICMP $11894^{\mathrm{PT}}$ & ND & 2 \\
\hline pv. daphniphylli & NCPPB $3617^{\mathrm{PT}}$ & ND & $\ldots$ \\
\hline pv. delphinii & LMG $5381^{\mathrm{PT}}$ & 3 & $\ldots$ \\
\hline pv. dysoxyli & LMG $5062^{\mathrm{PT}}$ & 1 & $\ldots$ \\
\hline pv. eriobotryae & LMG $2184^{\mathrm{PT}}$ & 2 & $\ldots$ \\
\hline pv. garcae & LMG 5064 & 4 & $\ldots$ \\
\hline pv. glycinea & LMG $5066^{\mathrm{PT}}$ & 2 & $\ldots$ \\
\hline pv. helianthi & LMG $5067^{\mathrm{PT}}$ & 7 & $\ldots$ \\
\hline pv. hibisci & NCPPB $3682^{\mathrm{PT}}$ & 2 & $\cdots$ \\
\hline pv. lachrymans ${ }^{\mathrm{c}}$ & CFBP $6463^{\mathrm{PT}}$ & 2 & $\ldots$ \\
\hline pv. lapsa & LMG $2206^{\mathrm{PT}}$ & 1 & $\ldots$ \\
\hline pv. maculicola & CFBP $1657^{\mathrm{PT}}$ & 3 & $\ldots$ \\
\hline pv. mellea & LMG $5072^{\mathrm{PT}}$ & 2 & $\ldots$ \\
\hline pv. mori & LMG 5074 ${ }^{\mathrm{PT}}$ & 2 & $\ldots$ \\
\hline pv. myricae & LMG $5668^{\mathrm{PT}}$ & 2 & $\ldots$ \\
\hline pv. oryzae & LMG $10912^{\mathrm{PT}}$ & 4 & $\ldots$ \\
\hline pv. papulans & LMG 5076 ${ }^{\mathrm{PT}}$ & 1 & $\ldots$ \\
\hline pv. passiflorae & LMG $5185^{\mathrm{PT}}$ & 3 & $\ldots$ \\
\hline pv. persicae & NCPPB $2761^{\mathrm{PT}}$ & 3 & $\cdots$ \\
\hline pv. phaseolicola & LMG $2245^{\mathrm{PT}}$ & 2 & $\ldots$ \\
\hline pv. philadelphi & NCPPB $3257^{\mathrm{PT}}$ & 3 & $\dddot{9}$ \\
\hline pv. photiniae & NCPPB $3688^{\mathrm{PT}}$ & 2 & $\ldots$ \\
\hline pv. pisi & NCPPB $2585^{\mathrm{PT}}$ & 1 & $\ldots$ \\
\hline pv. primulae & LMG $2252^{\mathrm{PT}}$ & 3 & $\ldots$ \\
\hline pv. rhaphiolepidis & NCPPB $3618^{\mathrm{PT}}$ & ND & $\ldots$ \\
\hline pv. ribicola & LMG $2276^{\mathrm{PT}}$ & 3 & $\ldots$ \\
\hline pv. savastanoi & LMG $2209^{\mathrm{PT}}$ & 2 & $\ldots$ \\
\hline pv. sesami & LMG $2289^{\mathrm{PT}}$ & 2 & $\cdots$ \\
\hline pv. solidagae & ICMP $16925^{\text {PT }}$ & ND & 1 \\
\hline pv. spinaceae & ICMP $16929^{\mathrm{PT}}$ & ND & 3 \\
\hline pv. syringae & LMG $1247^{\mathrm{T}}$ & 1 & $\ldots$ \\
\hline pv. tabaci & NCPPB $1427^{\mathrm{PT}}$ & 2 & $\ldots$ \\
\hline pv. tagetis & LMG $5090^{\mathrm{PT}}$ & 7 & $\ldots$ \\
\hline pv. theae & LMG 5092 & 8 & $\ldots$ \\
\hline pv. tomato & CFBP $2212^{\mathrm{PT}}$ & 3 & $\ldots$ \\
\hline pv. ulmi & LMG $2349^{\mathrm{PT}}$ & 2 & $\ldots$ \\
\hline pv. viburni & LMG $2351^{\mathrm{PT}}$ & 3 & $\ldots$ \\
\hline pv. zizaniae & NCPPB $3690^{\mathrm{PT}}$ & 4 & $\ldots$ \\
\hline P. avellanae & LMG $21662^{\mathrm{T}}$ & 8 & $\ldots$ \\
\hline P. cannabina & & & \\
\hline pv. cannabina & CFBP $2341^{\mathrm{T}}$ & 9 & $\ldots$ \\
\hline pv. alisalensis & CFBP $6866^{\mathrm{PT}}$ & 9 & $\ldots$ \\
\hline pv. alisalensis & CFBP $1637^{d}$ & 9 & $\ldots$ \\
\hline
\end{tabular}

a Strains were obtained from Collection Française de Bactéries Phytopathogènes (CFBP); the International Collection of Micro-organisms from Plants, Landcare Research (ICMP); the Laboratorium voor Microbiologie University of Gent (LMG); or the National Collection of Plant Pathogenic Bacteria (NCPPB). Type and pathotype strains are designated by the superscripts $\mathrm{T}$ and PT, respectively.

${ }^{\mathrm{b}} \mathrm{ND}=$ not determined.

c According to Bull et al. (11), the pathotype strain of P. syringae pv. lachrymans is unsuitable. We included it here because it was previously classified by Gardan et al. (21) into genomospecies 2 and our data confirm this finding.

${ }^{\mathrm{d}}$ P. syringae pv. maculicola strain B70 isolated from Williams and Keen in 1965 is otherwise known as CFBP 1637, M4, ES4326, and ICMP 4326. This pathogen was recently transferred to $P$. cannabina pv. alisalensis (12). 
tions on leaves in control treatments. The resulting tissue suspensions were streaked on KMB supplemented with boric acid, cephalexin, and cycloheximide (KBC) (52) and incubated at $27^{\circ} \mathrm{C}$. After 4 to 5 days, single colonies were purified and stored for future verification of their identities. In each experiment, three to six plants were inoculated with each isolate. An isolate or strain was considered pathogenic on a host when pathogenicity was confirmed in two independent experiments and the reisolates had rep-PCR DNA banding patterns and character states for fluorescence, ice nucleation, and gelatin hydrolysis identical to the isolates used to inoculate the plants. Isolates were considered nonpathogenic when there were no symptoms or bacteria isolated on KBC from inoculated plants or were not confirmed to be the isolate used to inoculate the plant.

MLST. In order to evaluate MLST and PAMDB (1) as a resource to rapidly allocate unidentified organisms to eight of the genomospecies described by Gardan et al. (21) and to identify pathovars of $P$. syringae, a blind test of the system was conducted. The type strain from $P$. tremae (originally designated as genomospecies 5) was not used in this study because it clusters with genomospecies 2 and is unlikely to be a distinct species (40). Purified DNA from 56 P. syringae pathotype strains and 10 isolates from parsley were transferred to Virginia Tech. No information about the 10 unknown isolates (including the host of origin) was given to the researchers at Virginia Tech except the specific isolate identification numbers. Gene fragments of the four loci gapl, gltA, gyrB, and $r p o D$ were amplified with primers described by Hwang et al. (23) and PCR products were sequenced as described in Yan et al. (63). Raw sequences were checked for quality and cut to size using Seqman (DNA*, Madison, WI). Sequences for all analyzed strains for each of the four loci were then compared with the alleles of the same loci already present in PAMDB using the BLAST program at the PAMDB website. When a sequence was found to be already in PAMDB, the PAMDB allele number for that locus was assigned to the strain. When a strain was found to have an allele that was not yet in PAMDB, this new allele was added to PAMDB with a new allele number. The new allele number was then assigned to the strain for the respective locus. Pairwise and average genetic distances were determined in Mega 5.0 Beta (57).

Allocation of unknowns to specific pathovars was made by identifying the pathotype strain or field strain most similar to the unknown in regard to overall DNA identity in the concatenated sequence of the four analyzed loci. Unknowns were also phylogenetically located in a phylogenetic tree built with the concatenated sequence of the four loci of all pathotype strains and all unknowns using the neighbor-joining algorithm in Megalign (DNA*). A Bayesian tree was also built. The substitution model that was found to best fit the data was GTR+I+G, applying the Akaike information criterion using the program $\mathrm{jModeltest}$ 0.1.1 (22,47). The program Mr. Bayes 3 (50) was then run for $10^{8}$ generations, which allowed for standard deviation of split frequencies to fall below 0.01. Sample frequency was 5,000 and burnin was 5,000 .

\section{RESULTS}

Isolation of bacteria from symptomatic parsley. Symptoms consisted of angular, irregularly shaped spots that generally measured 2 to $6 \mathrm{~mm}$ in diameter. Leaf spot color varied from light tan to dark brown. Spots were visible from both adaxial and abaxial sides of leaves. As disease progressed, the spots rarely coalesced or merged together. Leaf spots lacked the presence of fungal fruiting bodies, such as pycnidia, that are present if the parsley is infected with Septoria blight caused by Septoria petroselini. No fungi were isolated from the nine disease outbreaks sampled. Numerous fluorescent bacteria grew from surfacedisinfested tissue. Seventy individual colonies from each of the nine disease outbreaks were purified and were stored for evaluation.

Characterization of genomic structure using rep-PCR. Primers corresponding to the BOX1A subunit of the BOX element annealed to genomic DNA and generated unique DNA fragment-banding patterns for each pathotype of $P$. syringae evaluated (Fig. 1A). The 70 isolates from parsley were characterized by one of two distinct rep-PCR DNA fragment-banding patterns (pattern 1 and 2) and representatives are shown in Figure 1A. For one disease outbreak in 2002, both types of bacteria (referred to as pattern 1 and pattern 2 isolates) were isolated from lesions on separate plants. Pattern 1 or pattern 2 isolates, but not both, were identified from the remaining eight independent outbreaks. Similar results were obtained using enterobacterial repetitive intergenic consensus primers in rep-PCR reactions (data not shown).

TABLE 2. Source and genetic characterization of Pseudomonas syringae isolates from plants in the family Apiaceae from the central coastal California

\begin{tabular}{|c|c|c|c|c|c|c|}
\hline \multirow[b]{2}{*}{ Strains } & \multirow[b]{2}{*}{ Parsley outbreak } & \multicolumn{3}{|c|}{ Original disease outbreak } & \multirow[b]{2}{*}{ rep-PCR ${ }^{\mathrm{a}}$} & \multirow[b]{2}{*}{ Genomospecies } \\
\hline & & Host & Location & Date & & \\
\hline BS426 & 1 & Parsley & Salinas Valley, CA & 2003 & 1 & 3 \\
\hline $\mathrm{BS} 463^{\mathrm{c}}$ & 3 & Flat-leaf parsley & Salinas, CA & 2002 & 1 & 3 \\
\hline BS2715 & 8 & Parsley & Hollister, CA & 2009 & 1 & 3 \\
\hline $1089-5$ & $\ldots$ & Celery & Salinas, CA (62) & 1989 & 3 & 3 \\
\hline BS252 & $\ldots$ & Celery & Salinas, CA & 2001 & 1 & ND \\
\hline BS269 & $\ldots$ & Celery & King City, CA & 2001 & 1 & ND \\
\hline BS329 & $\ldots$ & Celery & Salinas, CA & 2002 & 1 & ND \\
\hline BS351 & $\ldots$ & Celery & Salinas, CA & 2003 & 1 & ND \\
\hline BS545 & $\ldots$ & Celery & Salinas, CA & 2003 & 1 & ND \\
\hline BS456 & 2 & Curled-leaf parsley & Salinas, CA & 2003 & 2 & 9 \\
\hline $\mathrm{BS} 462^{\mathrm{c}}$ & 3 & Flat-leaf parsley & Salinas, CA & 2002 & 2 & 9 \\
\hline BS821 & 4 & Flat-leaf parsley & Yuma, AZ & 2005 & 2 & 9 \\
\hline BS2059 & 5 & Flat-leaf parsley & Santa Maria, CA & 2006 & 2 & 9 \\
\hline BS2091 & 6 & Double-curled parsley & Turlock, CA & 2006 & 2 & 9 \\
\hline BS2097 & 7 & Flat-leaf parsley & Turlock, CA & 2006 & 2 & 9 \\
\hline BS2705 & 9 & Parsley & King City, CA & 2009 & 2 & 9 \\
\hline BS525 & $\ldots$ & Cilantro & Soledad, CA & 2003 & 2 & ND \\
\hline BS2505 & $\ldots$ & Cilantro & San Diego County, CA & 1990 & 2 & ND \\
\hline BS2508 & $\ldots$ & Cilantro & Monterey County, CA & 1990 & 2 & ND \\
\hline BS2890 & $\ldots$ & Cilantro & King City, CA & 2010 & 2 & ND \\
\hline
\end{tabular}

a Polymerase chain reaction primed by repetitive extragenic sequences (rep-PCR) pattern.

b Genomospecies as determined by this study; ND = not determined.

c Represent isolates from different plants in the same field. 
The pattern 1 DNA fragment-banding pattern corresponded to parsley isolates from three disease outbreaks on parsley. Pattern 1 was similar ( $>92 \%$ similarity) but not identical to the rep-PCR DNA banding pattern of the pathotype strain of $P$. syringae pv. apii (Fig. 1A). DNA fragment-banding pattern 1 had four DNA fragments $(512$ to $1,544 \mathrm{~kb})$ that were not present in the DNA fragment-banding pattern of the pathotype strain $P$. syringae pv. apii. Additionally, an $\approx 2,182-\mathrm{kb}$ fragment was present in the DNA fragment-banding pattern of the pathotype strain of $P$. syringae pv. apii but not in DNA fragment-banding pattern 1 from parsley isolates. However, DNA fragment-banding pattern 1 was identical to the DNA fragment-banding patterns from previously identified $P$. syringae pv. apii strains isolated from celery with northern blight in the Salinas Valley (Fig. 1B). The banding pattern of strain 1089-5 of $P$. syringae pv. apii isolated in 1989 from celery with bacterial blight in the Salinas Valley, CA (65) was intermediate between the pathotype strain and the pattern 1 isolates.

Isolates with the DNA fragment-banding pattern 2 were isolated from seven disease outbreaks. Pattern 2 was identical to the rep-PCR DNA fragment-banding pattern of the pathotype strain of $P$. syringae pv. coriandricola (Fig. 1A) and to bacterial leaf spot pathogens isolated previously from symptomatic cilantro in the Salinas Valley (data not shown) (17). Additionally, the DNA fragment-banding pattern of the pathotype strain of $P$. syringae pv. coriandricola and the pattern 2 isolates were similar but not identical to $P$. cannabina pv. cannabina and $P$. cannabina $\mathrm{pv}$. alisalensis. In addition to having bands of different intensities, pattern 2 lacked a 2,747-kb band present in both $P$. cannabina pv. cannabina and $P$. cannabina pv. alisalensis patterns and lacked a $554-\mathrm{kb}$ band present in only the $P$. cannabina pv. cannabina pattern.

$16 \mathrm{~S}$ rDNA sequence analysis. The $16 \mathrm{~S}$ rDNAs of the pathotypes of $P$. syringae pv. coriandricola, $P$. syringae pv. apii, and the pattern 1 and 2 isolates were obtained and compared with each other and to reference strains. The 1,284 nucleotides represent the majority of the primary structure of the $16 \mathrm{~S}$ rDNA positions 111 to 1,395 based on Escherichia coli nomenclature (7).

Comparisons using BLAST (2) with sequences in public databases and some of the main Pseudomonas phylogenetic clusters previously defined revealed unequivocally that $P$. syringae $\mathrm{pv}$. coriandricola, $P$. syringae pv. apii, and the pattern 1 and 2 isolates are members of the $P$. syringae sensu lato cluster $(3,42)$. Strains with $99 \%$ similarity or greater to the pattern 1 and 2 isolates were all members of $P$. syringae sensu lato, including pathotype strains of $P$. syringae and $P$. cannabina. The pathotype strain of $P$. syringae pv. coriandrcola and the pattern 2 parsley isolates were identical to each other but differed from $P$. syringae and $P$. cannabina pathotypes at two locations: (i) at position 264, which had a $\mathrm{C}$ rather than a $\mathrm{T}$ found in $P$. syringae and $P$. cannabina; and (ii) at position 250, the pathotype strain of $P$. syringae pv. coriandricola and pattern 2 isolate BS462 had a G while the remaining pattern 2 isolates, the pathotype strains within $P$. syringae and P. cannabina, had an A at this position. The pattern 1 isolates differed from all $P$. syringae and $P$. cannabina strains evaluated, including $P$. syringae pv. apii, at position 455 , where the pattern 1 strains had an A and the other strains had a G.

Because of the high similarity between all sequences from members of $P$. syringae sensu lato and low bootstrap values (data not shown), we were unable to assign the unknown isolates from parsley to pathovars within $P$. syringae based on $16 \mathrm{~S}$ rDNA sequence analysis. Sequences were submitted to GenBank and were given accession numbers HQ584978 to HQ584987.

Phenotypic characterization of bacterial pathogens. Phenotypic characters for the organisms evaluated are given in Table 3. All organisms evaluated, including the pathotype strains of $P$. syringae pv. apii, $P$. syringae pv. coriandricola, and $P$. syringae pv. syringae and the isolates from parsley, were levan and $\mathrm{KOH}$ positive (i.e., gram negative) and produced a hypersensitive response on tobacco. The organisms were oxidase and arginine dihydrolase negative and did not rot potato slices, indicating that they all belonged to Lelliot's LOPAT group 1 (34). Genes for the production of coronatine, syringomycin, tabtoxin, and tagititoxin were not amplified for the pathotype strains of $P$. syringae pv. apii and $P$. syringae pv. coriandricola or any of the parsley isolates (data not shown).

Pattern 1 isolates from parsley, $P$. syringae pv. apii, and $P$. syringae pv. syringae were fluorescent on KMB. Two pathotype strains of $P$. syringae pv. apii from two different collections were evaluated and they were identical for all tests, except that one strain was able to hydrolyze gelatin as expected and one was not. All of the pattern 1 isolates from parsley were able to hydrolyze gelatin. The pattern 1 isolates did not nucleate ice and differed from the $P$. syringae pv. apii pathotypes which were able to nucleate ice. Pattern 1 isolates and $P$. syringae pv. apii pathotypes were identical in terms of utilization patterns of the 50 carbon sources tested. The $P$. syringae pv. apii and $P$. syringae pv. coriandricola pathotypes and all strains isolated from diseased parsley utilized glycerol, L-arabinose, D-ribose, D-galactose, Dglucose, D-fructose, D-mannose, Inositol, D-mannitol, D-sorbitol, D-saccharose, D-arabitol, and potassium gluconate. All other carbon sources in the API $50 \mathrm{CH}$ strips were not utilized, except D-xylose (see below).

The $P$. syringae pv. coriandricola pathotype and the pattern 2 isolates differed from $P$. syringae pv. apii in that they did not

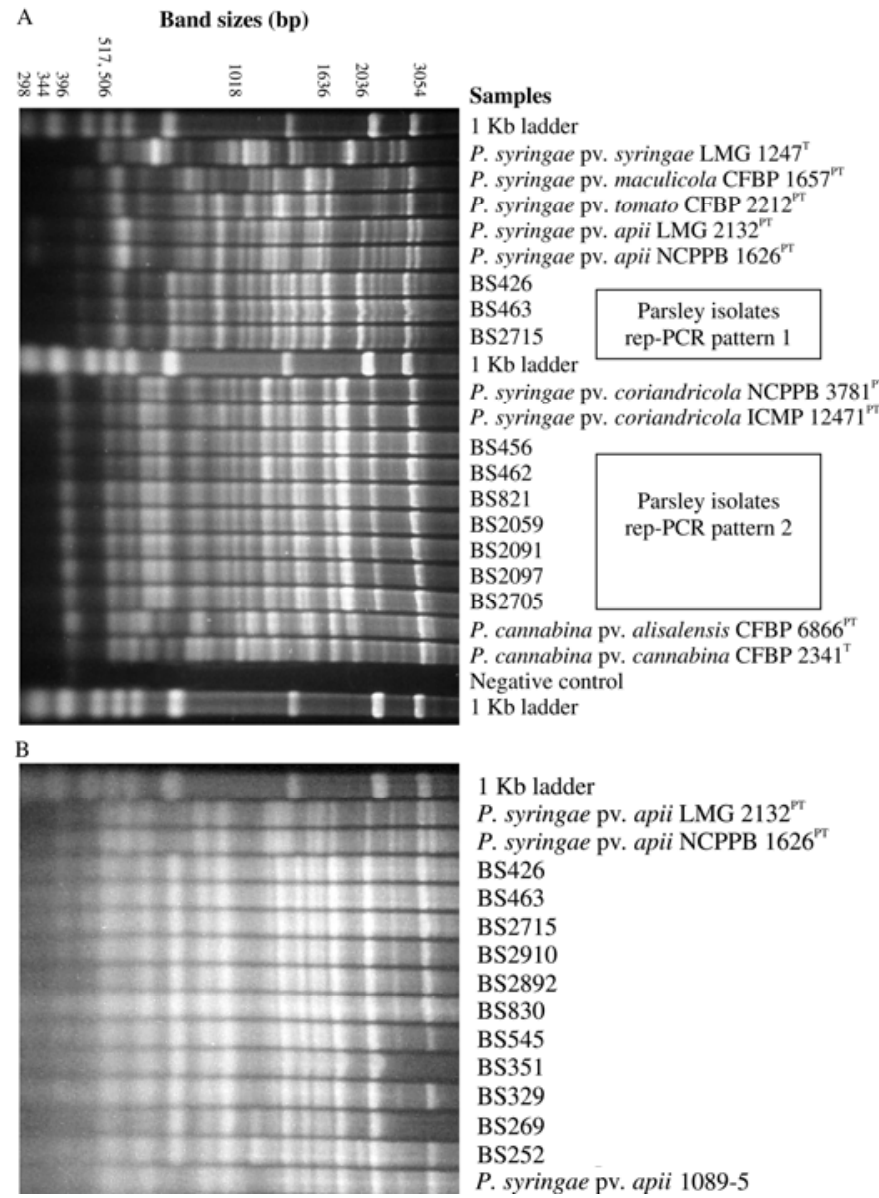

Fig. 1. DNA fragment-banding patterns from DNA amplified using repetitive extragenic palindromic sequence polymerase chain reaction (rep-PCR) with the BOX-A1R primers. A, Parsley isolates and B, Pseudomonas syringae pv. apii isolates from parsley and celery grown in central coastal California. A portion of the PCR products $(9 \mu \mathrm{l})$ was loaded into a $1.5 \%$ agarose gel, and electrophoresis was performed at $70 \mathrm{~V}$ for $12 \mathrm{~h}$ in $0.5 \times$ Tris-acetate-EDTA buffer. The 1-kb DNA ladder band sizes are given in base pairs. 
fluoresce on $\mathrm{KMB}$ and they did not utilize D-xylose as a carbon source whereas $P$. syringae pv. apii and pattern 1 isolates did. The $P$. syringae $\mathrm{pv}$. coriandricola pathotype and pattern 2 isolate, BS462, did not hydrolyze gelatin but the remaining seven of the pattern 2 isolates did. All of the pattern 2 isolates and the $P$. syringae pv. coriandricola pathotype nucleated ice.

All of the unknowns evaluated in these experiments had fatty acid profiles that matched the characteristics of strains from subgroup 1a as described by Stead (56), characterized by profiles having 12:0 2-OH, 12:0 3-OH, and <6\% 10:0 3-OH. Additionally, the unknowns produced 10:0 $30 \mathrm{H}, 12: 0,14: 0,16: 0,16: 1 \omega 7 \mathrm{c}$, 18:0, and 18:1 $\omega 7 \mathrm{c}$ fatty acids (Table 3 ). Likewise, all strains produced 18:1 o7c 11-methyl and either didn't produce 10:0 or only produced trace amounts $(<1.5 \%)$. Of all the strains tested, only the pathotype strain of $P$. syringae pv. apii produced small amounts $(>0.3 \%)$ of 17:0 iso.

Demonstration of Koch's postulates and host range evaluation. Bacterial leaf spots identical to those observed in disease outbreaks in 2003 to 2009 were observed on parsley plants inoculated with the pathotype strains of $P$. syringae pv. apii, $P$. syringae pv. coriandricola, and unknown isolates from parsley. Likewise, the parsley isolates and the pathotypes of $P$. syringae pv. apii and $P$. syringae pv. coriandricola caused similar symptoms on celery and coriander or cilantro. No differences in symptoms were detected among plants inoculated with any of these pathogens on any of the hosts. For all these organisms, reisolates obtained from lesions on parsley, celery, and coriander or cilantro had identical rep-PCR patterns and characters for fluorescence, ice nucleation, and gelatin hydrolysis as the isolates used to inoculate the plants from which the reisolate was obtained. No bacteria were isolated on KBC from uninoculated plants or plants inoculated with $P$. syringae pv. syringae.

MLST. Allele sequences of the four loci gltA, gapl, gyrB, and $r p o D$ (23) were concatenated for all pathotype strains and unknown strains listed in Table 1. A phylogenetic tree was then built using the neighbor-joining algorithm (Fig. 2). A Bayesian tree with the same overall topology was also obtained (data not shown). Based on the assignment of pathotype strains to genomospecies performed by Gardan et al. (21), it was possible to correlate the branches of the phylogenetic trees to genomospecies. In only one case was assignment somewhat ambiguous: in our tree, $P$. avellanae (genomospecies 8) clusters with three pathotype strains of genomospecies 3 ( $P$. syringae pvs. viburni, delphinii, and passiflorae) on one branch within a larger clade containing the genomospecies 8 strains $P$. syringae pv. theae and $P$. syringae pv. actinidiae. Additionally, although all pathotype strains belonging to genomospecies 2 cluster together in one clade, there is no significant bootstrap support for this clade. This low support may be due to a recombination event suggested by Sarkar and Guttman (51) involving the gene gyrB during the early divergence of genomospecies 1 and 2 (corresponding to phylogenetic groups 3 and 4 in Sarkar and Guttman) (51).

To determine genetic diversity of $P$. syringae sensu lato and genetic diversity within each genomospecies, average and maximum genetic distances were calculated using all considered type strains and pathotype strains representing the various genomospecies (Table 4). Because some genomospecies only contain two described pathovars, these genomospecies have, as expected, small average genetic distance (for example, genomospecies 7 and 8). Genomospecies containing a relatively large number of pathovars have generally a high average genetic distance (for example, genomospecies 1 and 2). However, there were some exceptions. In particular, genomospecies 3 , containing 10 pathotype strains, had a small average genetic distance (0.014), indicating that many pathovar strains in this genomospecies are very closely related. We then compared pairwise genetic distance based on our MLST data with the DDH values obtained for the same strains by Gardan et al. (21). There is an almost linear relationship between these two measurements of genetic diversity (Fig. 3). The DDH value of $70 \%$ is used as cutoff to determine whether two bacterial strains belong to the same species or genomospecies (61). This value corresponds approximately to a genetic distance of 0.0375 in the graph. Interestingly, almost all pairs of strains have either DDH values clearly $>70 \%$ (and genetic distance $<0.0375$ ) or DDH values $<70 \%$ (and genetic distances $>0.0375$ ). Therefore, it appears straightforward to assign strains to genomospecies using genetic distance values obtained by MLST.

In a blind study comparing the parsley unknowns with all pathotypes and type strains of $P$. syringae sensu lato, the unknown isolate BS2705 was found to be identical to the pathotype strain of $P$. syringae pv. coriandricola. Six isolates (BS456, BS462, BS821, BS2059, BS2091, and BS2097) were found to have a genetic distance from the same pathotype strain of only 0.006 (Supplementa1 Table 2 for all pairwise genetic distances within genomospecies 9) and to be located on a neighboring branch in the tree in Figure 2. These seven unknown isolates corresponded to the pattern 2 isolates described above. The two branches belong to the same clade, with a $100 \%$ bootstrap support. This suggests that, based on their high genetic similarity to each other and their phylogenetic placement, all these isolates may be assigned to $P$. syringae pv. coriandricola. The genetic distance between the $P$. cannabina type strain and the $P$. syringae pv. coriandricola pathotype strain is 0.036 . This distance is similar to the maximum pairwise genetic distance of strains in genomospecies 1 and 2 and just below the 0.0375 cutoff, which we found to correspond to a

TABLE 3. Characterization of Pseudomonas syringae isolated from symptomatic parsley tissue ${ }^{\mathrm{a}}$

\begin{tabular}{|c|c|c|c|c|c|c|c|c|c|c|c|c|c|}
\hline \multirow[b]{3}{*}{ Strains } & \multicolumn{13}{|c|}{ P. syringae pv. } \\
\hline & \multirow{2}{*}{$\begin{array}{c}\text { syringae } \\
\text { LMG } \\
1247\end{array}$} & \multirow{2}{*}{$\begin{array}{c}\text { apii } \\
\text { LMG } \\
2132\end{array}$} & \multicolumn{3}{|c|}{ Pattern 1 isolates } & \multirow{2}{*}{$\begin{array}{c}\text { coriandricola } \\
\text { ICMP } \\
12471\end{array}$} & \multicolumn{7}{|c|}{ Pattern 2 isolates } \\
\hline & & & $\begin{array}{c}\text { BS } \\
426\end{array}$ & $\begin{array}{c}\text { BS } \\
463^{b}\end{array}$ & $\begin{array}{c}\text { BS } \\
2715\end{array}$ & & $\begin{array}{c}\text { BS } \\
456-\end{array}$ & $\begin{array}{c}\mathrm{BS} \\
462^{\mathrm{b}}\end{array}$ & $\begin{array}{l}\text { BS } \\
821\end{array}$ & $\begin{array}{c}\text { BS } \\
2059\end{array}$ & $\begin{array}{c}\text { BS } \\
2091\end{array}$ & $\begin{array}{c}\text { BS } \\
2097\end{array}$ & $\begin{array}{c}\text { BS } \\
2705\end{array}$ \\
\hline rep-PCR ${ }^{c}$ & ND & 4 & 1 & 1 & 1 & 2 & 2 & 2 & 2 & 2 & 2 & 2 & 2 \\
\hline Gelatin & ND & $+/-d$ & + & + & + & - & + & - & + & + & + & + & + \\
\hline Ice nucleation & + & + & - & - & - & + & + & + & + & + & + & + & + \\
\hline Fluorescence on $\mathrm{KMB}^{\mathrm{e}}$ & + & + & + & + & + & - & - & - & - & - & - & - & - \\
\hline Utilization of D-xylose & + & + & + & + & + & - & - & - & - & - & - & - & - \\
\hline Parsley ('Italian') ${ }^{\mathrm{f}}$ & - & + & + & + & + & + & + & + & + & + & + & + & + \\
\hline Celery ('Conquistador' several) & - & + & + & + & ND & + & + & + & ND & ND & ND & ND & ND \\
\hline Coriander or cilantro (cultivar) & - & + & + & + & ND & + & + & + & ND & ND & ND & ND & ND \\
\hline
\end{tabular}

a $\mathrm{ND}=$ not determined.

b Two different bacteria were isolated from symptomatic tissue from one sample of flat leaved parsley from this disease outbreak.

c Polymerase chain reaction primed by repetitive extragenic sequences (rep-PCR) pattern.

d LMG 2132 and NCPPB 1626, the pathotype of P. syringae pv. apii from two different collections, reacted differently for this assay.

e KMB = King's medium B agar.

${ }^{f}$ Dark green or Italian flat leaf were all the same. 
DDH value of 70\%. Therefore, the MLST results indicate that $P$. syringae pv. coriandricola is a member of $P$. cannabina. Additional discussion of arguments for and against assignment of $P$. syringae pv. coriandricola to $P$. cannabina are discussed in more detail below.

The remaining isolates BS426, BS463, and BS2715 (corresponding to the pattern 1 isolates) were identical to each other and were $100 \%$ identical to $P$. syringae pv. apii strain 1089-5 isolated from celery in the Salinas Valley in 1989 (65). However, the pattern 1 isolates have almost the same level of genetic distance from four different pathotype strains (Supplemental Table 3 for all pairwise genetic distances within genomospecies 9): $P$. syringae pv. apii (0.009), pv. anthirrini (0.008), pv. persicae (0.009), and pv. tomato (0.008). Therefore, assignment of pattern 1 isolates to one of these pathovars by MLST is not conclusive. However, because the pattern 1 isolates have very low genetic distance from these pathotype strains, which all belong to genomospecies 3 , and are located on the same clade with these strains with $100 \%$ bootstrap support, it is clear that these strains belong to genomospecies 3 .

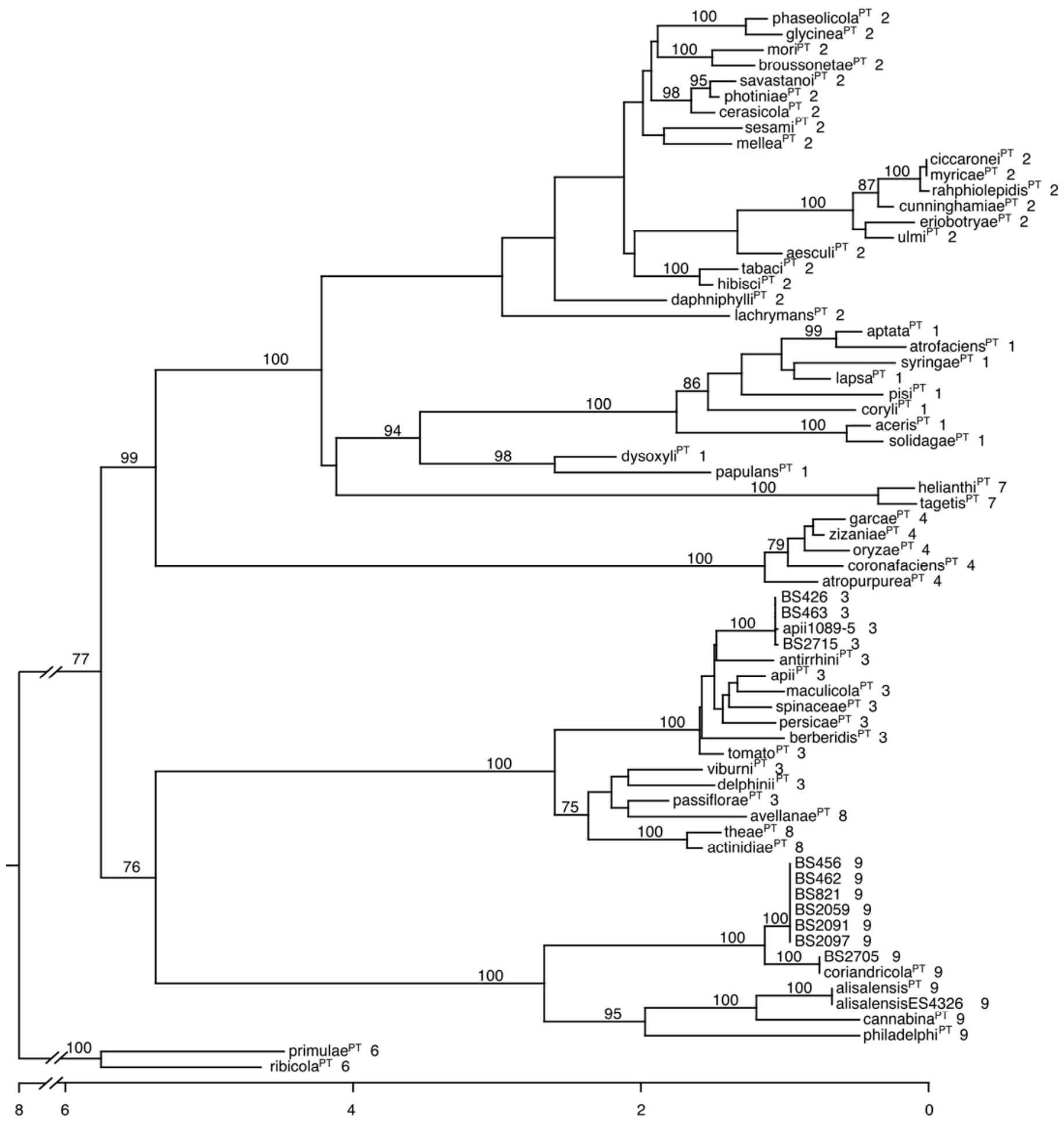

Fig. 2. Neighbor-joining tree of type and pathotype strains and isolates from parsley and celery from central coastal California. The tree was constructed in MegAlign (DNA*, Madison, WI) and 1,000 bootstrap replicates were performed with a starting seed of 111 . Bootstrap values of $\geq 70$ are shown above branches. Numbers to the right of pathovar names indicate to which genomospecies strains belong. 


\section{DISCUSSION}

This research evaluated the ability of MLST to identify unknown pathogens from a novel disease to the genomospecies and pathovar level within $P$. syringae sensu lato. The lack of clear criteria for identification of taxa within genomospecies of this group has prevented the elevation of phylogenetically distinct clades to individual species $(21,60)$. The data presented here provide the foundation for elevating $P$. syringae genomospecies to species by providing sequence-based criteria for allocating unknown organisms to these species. The blind evaluation of a novel disease of parsley caused by two different pathogens allowed for a rigorous evaluation of the ability of MLST to identify pathogens or indicate whether they represented novel taxa.

TABLE 4. Overall mean genetic distances between pathotype strains of Pseudomonas syringae sensu lato and genomospecies (G1 to 9)

\begin{tabular}{|c|c|c|c|c|c|c|}
\hline Strains & Number of strains & & Genetic distance between two strai & & Jukes Cantor $^{\mathrm{b}}$ & $P$ distance $^{\mathrm{b}}$ \\
\hline Sensu lato & 56 & 0.113 & atrofaciens|syringae|philadelphi & primulae & $0.072(0.003)$ & $0.068(0.003)$ \\
\hline G1 & 10 & 0.054 & atrofaciens & dysoxyli & $0.030(0.002)$ & $0.029(0.002)$ \\
\hline G2 & 20 & 0.044 & eriobotryae & lachrymans & $0.022(0.002)$ & $0.021(0.002)$ \\
\hline G3 & 10 & 0.024 & passiflorae|viburni & maculicola|berberidis & $0.014(0.002)$ & $0.014(0.002)$ \\
\hline G4 & 5 & 0.010 & garcae|zizaniae & atropurpurea & $0.007(0.001)$ & $0.007(0.001)$ \\
\hline G6 & 2 & 0.024 & primulae & ribicola & $0.024(0.003)$ & $0.023(0.003)$ \\
\hline G7 & 2 & 0.005 & helianthi & tagetis & $0.005(0.002)$ & $0.005(0.002)$ \\
\hline G8 & 3 & 0.017 & avellanae & theae & $0.012(0.002)$ & $0.012(0.002)$ \\
\hline G9 & 4 & 0.047 & philadelphi & coriandricola & $0.031(0.003)$ & $0.030(0.003)$ \\
\hline
\end{tabular}

a Maximum pairwise genetic distance found between any two pathotype strains calculated in MegAlign (DNA*, Madison, WI) for pathovar names of strains listed.

${ }^{\mathrm{b}}$ Mean distance and standard errors thereof were calculated in Mega 5.0 beta (54).

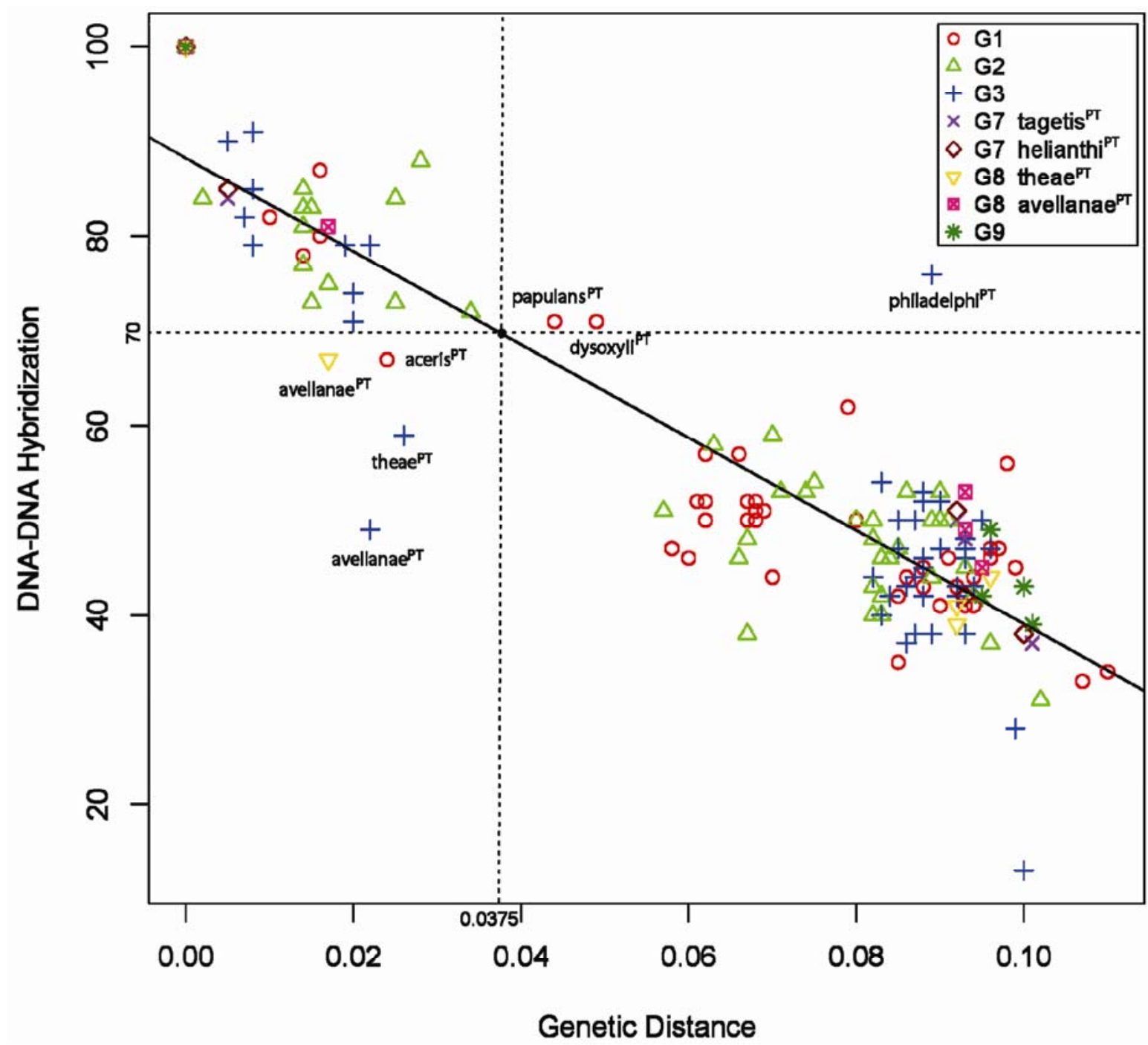

Fig. 3. Correlation between genetic distance based on multilocus sequence typing (MLST) and DNA/DNA hybridization (DDH) values. For each pair of pathotype strains analyzed with DDH by Gardan et al. (21) and with MLST here, the DDH value was plotted against the genetic distance (based on the concatenated sequence of the four gene fragments gyrB, rpoD, gltA, and gap1). Different symbols in different colors indicate which genomospecies (G1 to 9) reference strains were used. For example, each red circle represents the comparison of the genomospecies 1 reference strain, $P$. syringae pv. syringae, with each other pathotype strain. The regression line was determined to be $Y=88.45-491.98 X$, whereby $Y$ is the DDH value and $X$ is the genetic distance (calculated in R 2.9.0, http://www.r-project.org/). 
Two different pathogens, as indicated by different rep-PCR DNA fragment-banding patterns (pattern 1 and pattern 2), caused bacterial leaf spot diseases on parsley in nine separate disease outbreaks between 2002 and 2009. On one occasion (in 2002), both pathogens were isolated from different parsley plants in the same field. Both pathogens were members of $P$. syringae sensu lato according to LOPAT reactions, the kinds and quantity of fatty acids produced, and $16 \mathrm{~S}$ rDNA sequence analysis.

The pathotype strain of $P$. syringae pv. apii and the pattern 1 isolates from parsley were fluorescent on $\mathrm{KMB}$, utilized $\mathrm{D}$ xylose, and hydrolyzed gelatin. The pathotype strain of $P$. syringae pv. apii and the pattern 1 isolates were similar but not identical $(\approx 93 \%$ similarity) according to analysis of rep-PCR DNA fragment-banding patterns. Isolates of $P$. syringae pv. apii from celery grown in central coastal California in 2001 to 2010 had banding patterns that were identical to the parsley pattern 1 isolates. A previously identified $P$. syringae pv. apii strain isolated from celery in 1989 had a banding pattern that was intermediate to the pathotype strain and the pattern 1 isolates. These differences fall within the range of differences we have seen in banding patterns of individual strains within a pathovar. For example, the pathotype strain of $P$. cannabina pv. alisalensis and strains from arugula or radish have rep-PCR DNA fragment-banding patterns with similarity rankings of $\approx 86 \%$ (data not shown). The pathotype strain of $P$. syringae pv. apii and the pattern 1 isolates differed additionally in that the pathotype strains did not nucleate ice whereas the isolates from parsley did; however, variability for this character among strains within specific pathovars is known to occur (52). Based on these data and the host range data (presented below), we concluded that the pattern 1 isolates from parsley were $P$. syringae pv. apii.

The pattern 2 isolates were identified as $P$. syringae pv. coriandricola in part because they had rep-PCR DNA fragmentbanding patterns identical to the banding pattern of the pathotype of $P$. syringae $\mathrm{pv}$. coriandricola. Additionally, the pattern 2 isolates and the pathotype were not fluorescent on KMB, nucleated ice, and did not use D-xylose as a sole carbon source. Whereas the pathotype of $P$. syringae pv. coriandricola hydrolyzed gelatin, the pattern 2 isolates were variable for gelatin hydrolysis. To date, all other strains of $P$. syringae pv. coriandricola evaluated have been negative for gelatin hydrolysis (15, 17,59). In particular, isolate BS462 hydrolyzed gelatin and the $16 \mathrm{~S}$ rDNA sequence of this isolate was identical to that of the pathotype strain.

Koch's postulates were confirmed on parsley for both pattern 1 and pattern 2 isolates. Host range testing demonstrated that the pathogens from parsley were also pathogenic on celery and coriander or cilantro. Additionally, we demonstrated that the pathotype strains of both $P$. syringae pv. coriandricola and $P$. syringae pv. apii were pathogenic on parsley, celery, and coriander or cilantro. To our knowledge, this is the first report demonstrating natural infections of parsley by either of these pathogens and the first report of pathogenicity of $P$. syringae pv. coriandricola on celery or $P$. syringae pv. apii on coriander or cilantro.

$P$. syringae pv. coriandricola and $P$. syringae pv. apii are members of $P$. syringae sensu lato, a heterogeneous species made up of $\approx 60$ pathovars $(1,10-12,21,23,60)$, many of which have been placed in one of nine genomospecies (21). Allocation of new pathogens to one of the nine genomospecies is difficult because there are no phenotypic characters specific to the genomospecies, the host from which the pathogen was isolated does not necessarily correlate to genomospecies, few laboratories are able to conduct the DDH studies needed for genomospecies designations, and the data from previous studies are not portable $(1,49,60)$. Likewise, allocation of a new pathogen to an existing pathovar or designation of a new pathovar is difficult because it is not always obvious with which pathovars and associated hosts the new pathogen should be compared. A larger number of pathotypes may need to be imported for comparisons and host range tests, increasing the risk of introductions of pathogens to areas where they were previously not found. Recently, rep-PCR with the BOXA1R primer was used to separate $P$. syringae pathovars into their respective 9 genomospecies (40). Although the methods for comparing rep-PCR patterns are more accessible to most laboratories than DDH methods are, the data from rep-PCR, like DDH data, are not portable. For pathogen identification, laboratories would still need to have a complete set of pathovars available for comparisons.

Previously, we introduced the PAMDB website as resource for using MLST in pathogen population genetics, diversity, and classification (1). MLST is being used also to justify novel taxa as well as transfer and division of taxa $(8,12)$. Stackebrandt et al. (54) encouraged researchers to "propose new species based upon other genomic methods or techniques provided that they can demonstrate that, within the taxa studied, there is a sufficient degree of congruence between the technique used and DNA/DNA reassociation." Here, we added sequences of four genes for 56 pathotype strains of $P$. syringae sensu lato to PAMDB, thus providing nearly a complete cohort of $P$. syringae sensu lato pathotype sequences. The inclusion of pathotype strains in MLST allowed the derived phylogenetic tree to be correlated to the previously described genomospecies of $P$. syringae sensu lato (Fig. 3). There was a significant positive correlation between the genetic distance between concatenated sequences used in MLST and DDH levels. DDH levels of $70 \%$ correlated to $\approx 0.0375$ genetic distance between alleles used in MLST. Additionally, MLST was sufficient to correctly allocate the pattern 1 parsley isolates and the pathotype strain of $P$. syringae pv. apii to genomospecies 3, which is similar to the findings of Gardan et al. (21). MLST accurately placed pathotypes and unknown pathogens into genomospecies, thus forgoing the need for DDH studies. These findings are in line with previous MLST analyses of the genus Xanthomonas. MLST was able to allocate members of the genus Xanthomonas to various species: organisms with similarity values $<96 \%$ (corresponding to genetic distance of 0.04) were considered to be different species (64).

The accurate identification of $P$. syringae pv. coriandricola isolates by MLST among the unknown pathogens causing a previously unreported disease on parsley analysis was critical to testing the ability of MLST to allocate pathogens to the correct genomospecies and pathovar. $P$. syringae pv. coriandricola was proposed by Toben and Rudolf in 1996, just prior to the publication of the $P$. syringae genomospecies scheme by Gardan et al. (12), and is one of relatively few pathovars that have not been allocated to a genomospecies. MLST was able to allocate $P$. syringae pv. coriandricola to genomospecies $9, P$. cannabina, in the absence of DDH studies. The genetic distance between concatenated sequences from the pathotype strain of $P$. syringae pv. coriandricola and $P$. cannabina was 0.036 and, thus, just $<0.0375$, the genetic distance we found to correspond to the $70 \%$ DDH threshold used to differentiate species in this study. Genomospecies 9 was elevated to $P$. cannabina and $P$. cannabina was recently emended $(12,21)$ to include $P$. cannabina pv. alisalensis. The concatenated sequences from $P$. cannabina and $P$. cannabina pv. alisalensis have a genetic distance from each other of 0.013 and, because $P$. syringae pv. coriandricola appears to be more distantly related to $P$. cannabina than $P$. cannabina $\mathrm{pv}$. alisalensis, the inclusion of $P$. syringae pv. coriandricola in $P$. cannabina will significantly expand the known diversity of this species. Although these data demonstrate that $P$. syringae pv. coriandricola is a member of $P$. cannabina, further host-range testing is required to determine whether $P$. syringae pv. coriandricola is a novel pathovar within $P$. cannabina and the species may need to be further emended. Therefore, we are not making a formal proposal in this article to transfer the pathogen. 
In addition to indicating that $P$. syringae pv. coriandricola should be allocated to genomospecies 9 , these data also indicate that other pathotypes should be allocated to genomospecies as follows: genomospecies 1 ( $P$. syringae pv. coryli and $P$. syringae pv. solidagae), genomospecies 2 ( $P$. syringae pv. broussonetae, $P$. syringae pv. cunninghamiae, $P$. syringae pv. daphniphylli, and $P$. syringae pv. rahphiolepidis), and genomospecies 3 ( $P$. syringae pv. spinaceae). These data support findings of others $(36,40,44)$.

The pathotype strain of $P$. syringae pv. philadelphi clearly belongs to $P$. cannabina (Fig. 2), although it was assigned to genomospecies 3 by Gardan et al. (21). In our study and that of Parkinson et al. (44), the NCPPB pathotype strain for $P$. syringae pv. philadelphi was used while Gardan et al. (21) used the pathotype strain from the CFBP collection and, although unlikely, there could be differences between these two strains. Alternatively, whereas the four sequenced genes may be more similar to $P$. cannabina, $P$. syringae pv. philadelphi may have acquired virulence or other genes that are more similar to $P$. syringae pv. tomato and related genomospecies 3 strains.

The type strain of $P$. avellanae was assigned to genomospecies 8 by Gardan et al. (21), together with the pathotype $P$. syringae pv. theae, and work of Loreti et al. (36) included P. syringae pv. actinidiae in that clade. However, the probe from the pathotype of $P$. syringae pv. theae hybridized to DNA of the type strain of $P$. avellanae at levels marginal $(67 \pm 1.5)$ for consideration of inclusion of the same species (21). In the analysis presented here, $P$. avellanae clusters with three pathotype strains of genomospecies 3 (pathovars viburni, delphinii, and passiflorae) within a larger clade containing also the genomospecies 8 pathovars theae and actinidiae. Other data also support the idea that genomospecies 3 and 8 cluster together $(24,44)$. Here, we propose that the clade containing pathovars viburni, delphinii, passiflorae, theae, and actinidiae and $P$. avellanae may be better placed together in a new group because these strains have a maximum pairwise genetic distance of only 0.020 , far below the 0.0375 cut-off for separate species. Moreover, the fact that all of these strains are pathogens of perennial plants further suggests that they may share a common trait that makes them particularly fit on perennial plants.

Recently, $r p o D$ was shown to be useful in grouping pathovars into phylogroups that largely correspond to genomospecies of $P$. syringae (44). The approach is valuable but represents the phylogeny of a single gene, which does not necessarily represent the phylogeny of the organisms $(39,60)$. Although rpoD can assign pathovars to genomospecies, many pathovars have the same $r p o D$ allele and, therefore, cannot be distinguished. For example, $P$. cannabina pv. alisalensis and $P$. syringae pv. coriandricola have identical rpoD alleles, as do P. syringae pv. apii and $P$. syringae pv. antirrhini. Here, we solve this problem by including three genes in addition to $r p o D$ for more rigorous phylogenetic analysis.

This article provides the first demonstration that data provided in PAMDB, or by MLST in general, can accurately and rapidly allocate plant-pathogenic pseudomonads to the correct pathovar of $P$. syringae sensu lato. Based on the data set produced, the method offers a relatively simple way of identifying strains as members of known species, or of indicating their status as members of new species. For example, one of the pattern 2 parsley isolates (BS2705) was identical to the pathotype of $P$. syringae pv. coriandricola and the other isolates had a genetic distance of only 0.006 from this strain according to MLST. Thus, the pattern 2 parsley isolates were members of $P$. cannabina and most closely related to the pathotype of $P$. syringae pv. coriandricola.

In addition to demonstrating the ability of MLST to allocate unknown pathogens to known genomospecies and pathovars, MLST analysis indicated that pattern 1 pathogens are not identical to the pathotype strain of $P$. syringae pv. apii and warrant further research, thus indicating that MLST analyses should also be able to determine whether unknowns are likely to represent novel taxa. This tool should also help to determine whether strains have been misallocated to particular pathovars. PAMDB provides an extensive database of field and environmental isolates that goes beyond pathotype strains. Inferences made from analyses with a greater representation of pathogen diversity can direct further research by pinpointing differences in organisms that may describe recent evolutionary events or may indicate ecological differences among individual taxa. Analysis of the pattern 1 isolates from parsley is a good example of the usefulness of having both pathotype and additional field isolates in the PAMDB database. Identification of the pattern 1 isolates as $P$. syringae pv. apii was initially based on phenotypic characters, rep-PCR similarity, and host range analysis. These data have been sufficient for allocating the causal agent of northern bacterial blight of celery from the Salinas Valley to $P$. syringae pv. apii in previous studies $(28,30,35)$ and the standard for describing new pathovars (16). However, MLST analysis further defined the relationship of the $P$. syringae pv. apii isolates from celery and parsley in central coastal California to the pathotype of $P$. syringae pv. apii and related pathovars. MLST analysis demonstrated that the pattern 1 isolates were identical to $P$. syringae pv. apii strains obtained from diseased celery from the Salinas Valley, CA in 1989 (of which 1089-5 is a representative) but confirmed the differences between the pattern 1 isolates and the pathotype of $P$. syringae pv. apii isolated in 1942 . The structure of $P$. syringae pv. apii populations in central coastal California may be unique to this region or may represent a change in the pathogen population since the time of the isolation of the pathotype by Burkholder in 1942. The small genetic differences among the $P$. syringae pv. apii isolates from central coastal California compared with $P$. syringae pvs. apii (genetic distance of 0.009), anthirrini (0.008), persicae (0.009), and tomato (0.008) indicate the need for further host range evaluations comparing the pathotype strains with historical and modern P. syringae pv. apii strains worldwide. This represents a nice example of how powerful MLST is at identifying a small number of pathotype strains to use in host-range tests for host-range characterization of unknown isolates.

Severe and complete losses have been reported worldwide in coriander and cilantro production due to leaf spots and seed decay caused by $P$. syringae pv. coriandricola $(14,15,17,18,41$, 46,58,59). Verified clean seed should be used because seed transmission can be reduced only partially by seed treatments $(18,58)$. In addition to seed transmission, overhead irrigation and rain may result in the splash dispersal of $P$. syringae pv. coriandricola, which could be significant because populations as low as $1 \times 10^{2} \mathrm{CFU} / \mathrm{ml}$ can cause disease in coriander $(5,6)$. Likewise, northern bacterial blight on celery can reach $100 \%$ losses in California and overhead irrigation can increase the disease levels on new growth $(27,28,30)$. The disease is reported to be most severe on transplants produced in greenhouses $(27,28)$. The pathogen has been isolated from commercial seed lots (30).

This article demonstrates that both pathogens from parsley and the pathotype strains of $P$. syringae pv. coriandricola and $P$. syringae pv. apii cause similar leaf spot diseases on parsley, celery, and coriander or cilantro although, in other studies, $P$. syringae pv. coriandricola produced minor or no symptoms on celery $(15,46,59)$. Regardless, the expanded host range of these two pathogens and the potential of reciprocal infections on the original hosts from which they were isolated have epidemiological and practical implications. For example, in the intensive and extensive vegetable industry in California's Salinas Valley, multiple plantings of parsley, celery, or cilantro adjacent to or in rotation with each other can be made throughout a long (February to November) growing season. Therefore, diseased plantings of any of these crops may have significant impacts on adjacent and subsequent plantings. Thus, our host-range information is important to farmers and field advisors who need to take steps to 
prevent disease and maximize commodity quality. Although they cannot be distinguished by symptoms caused on these hosts, $P$. syringae pv. coriandricola and $P$. syringae pv. apii can easily be distinguished in culture because $P$. syringae pv. apii from celery is fluorescent on $\operatorname{KMB}(7,28,35)$ whereas $P$. syringae pv. coriandricola is not $(14,15,17,45,46,59)$. Nemeth et al. (43) may have isolated $P$. syringae pv. apii from coriander exhibiting bacterial blight and seed decay symptoms. These strains were fluorescent on KMB and hydrolyzed gelatin, as is expected for $P$. syringae pv. apii. Likewise, Taylor and Dudley (58) demonstrated that both fluorescent and nonfluorescent strains isolated from symptomatic coriander were pathogenic on coriander. Systematic evaluation of disease outbreaks on celery and coriander or cilantro are needed to determine whether $P$. syringae pv. coriandricola and $P$. syringae pv. apii cause disease in the reciprocal crops. Monitoring fluorescence of pathogens isolated from celery and coriander or cilantro on KBC followed by rep-PCR or MLST analysis of isolated strains will help to identify whether and to what degree these relationships occur in the field.

\section{ACKNOWLEDGMENTS}

Research in the Vinatzer lab was funded by the National Science Foundation (Award IOS 0746501). The United States Department of Agriculture is an equal opportunity provider and employer. We thank P. Goldman, K. Kammeijer, P. Ayala, S. Mauzey, R. Lomeli, I. Rubio, S. Gebben, and N. Gomez for technical assistance; and A. Aspin for providing NCPPB strains.

\section{LITERATURE CITED}

1. Almeida, N. F., Yan, S., Cai, R., Clarke, C. R., Morris, C. E., Schaad, N. W., Schuenzel, E. L., Lacy, G. H., Sun, X., Jones, J. B., Castillo, J. A., Bull, C. T., Leman, S., Guttman, D. S., Setubal, J. C., and Vinatzer, B. A. 2010. PAMDB, a multilocus sequence typing and analysis database and website for plant-associated microbes. Phytopathology 100:208-215.

2. Altschul, S. F., Madden, T. L., Schäffer, A. A., Zhang, J., Zhang, Z., Miller, W., and Lipman, D. J. 1997. Gapped BLAST and PSI-BLAST: A new generation of protein database search programs. Nucleic Acids Res. 25:3389-3402.

3. Anzai, Y., Kim, H., Park, J. Y., Wakabayashi, H., and Oyaizu, H. 2000. Phylogenetic affiliation of the pseudomonads based on 16S rRNA sequence. Int. J. Syst. Evol. Microbiol. 50:1563-1589.

4. Bereswill, S., Bugert, P., Volksch, B., Ullrich, M., Bender, C. L, and Geider, K. 1994. Identification and relatedness of coronatine-producing Pseudomonas syringae pathovars by PCR analysis and sequence determination of the amplification products. Appl. Environ. Microbiol. 60:2924-2930.

5. Bock, C., and Refshauge, S. 2005. Infection and development of Pseudomonas syringae pv. coriandricola in coriander. (Abstr.) Phytopathology 95:S11.

6. Bock, C., and Refshauge, S. 2005. Splash dispersal of Pseudomonas syringae pv. coriandricola among seedlings of coriander. (Abstr.) Phytopathology 95:S12.

7. Bradbury, J. F. 1986. Guide to Plant Pathogenic Bacteria. CAB International, Slough, UK.

8. Brady, C. L., Venter, S. N., Cleenwerck, I., Engelbeen, K., Vancanneyt, M., Swings, J., and Coutinho, T. A. 2009. Pantoea vegans sp. nov., Pantoea eucalypti sp. nov., Pantoea deleyi sp. nov. and Pantoea anthophila sp. nov. Int. J. Syst. Evol. Microbiol. 59:2339-2345.

9. Brosius, J., Palmer, M. L., Kennedy, P. J., and Noller, H. F. 1978. Complete nucleotide sequence of a $16 \mathrm{~S}$ ribosomal RNA gene from Escherichia coli. Proc. Natl. Acad. Sci. USA 75:4801-4805.

10. Bull, C. T., De Boer, S. H., Denny, T. P., Firrao, G., Fischer-Le Saux, M., Saddler, G. S., Scortichini, M., Stead, D. E., and Takikawa, Y. 2008. Demystifying nomenclature of bacterial plant pathogens. J. Plant Pathol. 90:403-417.

11. Bull, C. T., De Boer, S. H., Denny, T. P., Firrao, G., Fischer-Le Saux, M., Saddler, G. S., Scortichini, M., Stead, D. E., and Takikawa, Y. Comprehensive list of names of plant pathogenic bacteria, 1980-2007. J. Plant Pathol. 92:551-592.

12. Bull, C. T., Manceau, C., Lydon, J., Kong, H., Vinatzer, B. A., and Fischer-Le Saux, M. 2010. Pseudomonas cannabina pv. cannabina pv. nov., and Pseudomonas cannabina pv. alisalensis (Cintas Koike and Bull 2000) comb. nov., are members of the emended species Pseudomonas cannabina (ex Sutic \& Dowson 1959) Gardan, Shafik, Belouin, Brosch, Grimont \& Grimont 1999. Syst. Appl. Microbiol. 33:105-115. doi: 10.1016/j.syapm.2010.02.001.

13. Canteros de Echenique, B. I., Zagory, D., and Stall, R. E. 1985. A medium for cultivation of the B-strain of Xanthomonas campestris pv. citri, cause of cancrosis B in Argentina and Uruguay. Plant Dis. 69:122-123.

14. Cazorla, F. M., Vázquez, M. A., Rosales, J., Arrebola, E., Navarro, J., Pérez-García, A., and de Vincente, A. 2005. First report of bacterial leaf spot (Pseudomonas syringae pv. coriandricola) of coriander in Spain. J. Phytopathol. 153:181-184.

15. Cerkauskas, R. F. 2009. Bacterial leaf spot of cilantro (Coriandrum sativum) in Ontario. Can. J. Plant Pathol. 31:16-21.

16. Cintas, N. A., Koike, S. T., and Bull, C. T. 2002. A new pathovar, Pseudomonas syringae pv. alisalensis pv. nov., proposed for the causal agent of bacterial blight of broccoli and broccoli raab. Plant Dis. 86:992998.

17. Cooksey, D. A., Azad, H. R., Paulus, A. O., and Koike, S. T. 1991. Leaf spot of cilantro in California caused by a nonfluorescent Pseudomonas syringae. Plant. Dis. 75:101.

18. Dennis, J., and Wilson, J. 2002. Disease control in coriander and other spice seeds. Rural Industries Research and Development Corporation Research Paper 02/147.

19. Dye, D. W., Bradbury, J. F., Goto, M., Hayward, A. C., Lelliott, R. A., and Schroth, M. N., 1980. International standards for naming pathovars of phytopathogenic bacteria and a list of pathovar names and pathotype strains. Rev. Plant Pathol. 59:153-168.

20. Elena, K., Alivizatos, A. S., and Varveri, C. 2008. New plant pathogens reported in Greece, 1990-2007. Hellenic Plant Prot. J. 1:1-25.

21. Gardan, L., Shafik, H., Belouin, S., Broch, R. Grimont, F., and Grimont, P. A. D. 1999. DNA relatedness among the pathovars of Pseudomonas syringae and description of Pseudomonas tremae sp. nov. and Pseudomonas cannabina sp. nov. (ex Sutic and Dowson 1959). Int. J. Syst. Bacteriol. 49:469-478.

22. Guindon, S., and Gascuel, O. 2003. A simple, fast, and accurate algorithm to estimate large phylogenies by maximum likelihood. Syst Biol. 52:696704.

23. Hwang, M. S. H., Morgan, R. L. Sarkar, S. F. Wang, P. W., and Guttman, D. S. 2005. Phylogenetic characterization of virulence and resistance phenotypes of Pseudomonas syringae. Appl. Environ. Microbiol. 71:5182-5191.

24. Inoue, Y., and Takikawa, Y. 2006. The $h r p Z$ and $h r p A$ genes are variable, and useful for grouping Pseudomonas syringae bacteria. J. Gen. Plant Pathol. 72:26-33.

25. Jagger, I. C. 1921. Bacterial leafspot disease of celery. Phytopathology 21:185-188.

26. King, E. O., Ward, M. K., and Raney, D. E. 1954. Two simple media for the demonstration of pyocyanin and fluorescin. J. Lab. Clin. Med. 44:301307.

27. Koike, S. T., and Bishop, A. L. 1990. Bacterial leaf spot of celery caused by Pseudomonas syringae pv. apii in California. (Abstr.) Phytopathology 80:890.

28. Koike, S. T., Little, E. L., Bishop, A. L., and Gilbertson, R. L. 1994. New celery disease appears in California. Calif. Agric. 48:32-34.

29. Kong, H., Patterson, C. D., Zhang, W., Takikawa, Y., Suzuki, A., and Lydon, J. 2004. A PCR protocol for the identification of $P$. syringae pv. tagetis based on genes required for tagetitoxin production. Biol. Control 30:83-89.

30. Lacy, M. L., Berger, R. D., Gilbertson, R. L., and Little, E. L. 1996. Current challenges in controlling disease of celery. Plant Dis. 80:10841091.

31. Lane, D. J. 1991. 16S/23S rRNA sequencing. Pages 115-175 in: Nucleic Acid Techniques in Bacterial Systematics. E. Stackebrandt and M. Goodfellow, eds. John Wiley and Sons, New York.

32. Lang, E., Griese, B., Spröer, C., Schumann, P., Steffen, M., and Verbarg, S. 2007. Characterization of 'Pseudomonas azelaica' DSM 9128, leading to emended descriptions of Pseudomonas citronellolis Seubert 1960 (Approved Lists 1980) and Pseudomonas nitroreducens Iizuka and Komagata 1964 (Approved Lists 1980), including Pseudomonas multiresinivorans as its later heterotypic synonym. Int. J. Syst. Evol. Microbiol. 57:878-882. doi: 10.1099/ijs.0.64849-0.

33. Lapage, S. P., Sneath, P. H. A., Lessel, E. F., Skerman, V. B. D., Seeliger, H. P. R., and Lark, W. A., eds. 1992. International Code of Nomenclature of Bacteria (1990 Revision). American Microbiological Society, Washington, DC.

34. Lelliott, R. A., Billing, E., and Hayward, A. C. 1966. A determinative scheme for the fluorescent plant pathogenic pseudomonads. J. Appl. Bacteriol. 29:470-489.

35. Little, E. L., Koike, S. T., and Gilbertson, R. L. 1997. Bacterial leaf spot of celery in California: Etiology, epidemiology, and role of contaminated seed. Plant Dis. 81:892-896. 
36. Loreti, S., Gervasi, F, Gallelli, A, and Scortichini, M. 2008. Further molecular characterization of Pseudomonas syringae pv. coryli. J. Plant Pathol. 90:57-64.

37. Lydon, J., and Patterson, C. D. 2001. Detection of tabtoxin-producing strains of Pseudomonas syringae by PCR. Lett. Appl. Microbiol. 32:166170 .

38. Maiden, M. C. J., Bygraves, J. A., Feil, E., Morelli, G., Russell, J. E., Urwin, R., Zhang, Q., Zhou, J., Zurth, K., Caugant, D. A., et al. 1998. Multilocus sequence typing: A portable approach to the identification of clones within populations of pathogenic microorganisms. Proc. Natl. Acad. Sci. USA 95:3140-3145.

39. Maiden, M. C. J. 2006. Multilocus sequence typing of bacteria. Annu. Rev. Microbiol. 60:561-588.

40. Marques, A. S. A, Marchaison, A., Gardan, L., and Samson, R. 2008. BOX-PCR-based identification of bacterial species belonging to Pseudomonas syringae-P. viridiflava group. Genet. Mol. Biol. 31:106-115.

41. Mavridis, A., Meier zu Beerentrup, H., and Rudolph, K. 1989. Bacterial umbel blight of coriander in West Germany. Pages 635-640 in: Plant Pathogenic Bacteria, Z. Klement, ed. Proc. 7th Int. Conf. Plant Pathol. Bacteriol. Budapest.

42. Moore, E. R. B., Mau, M., Arnscheidt, A., Böttger, E. C., Hutson, R. A., Collins, M. D., van de Peer, Y., de Wachter, R., and Timmis, K. N. 1996. The determination and comparison of the 16S rRNA gene sequences of species of the genus Pseudomonas (sensu stricto) and estimation of the natural intragenic relationships. Syst. Appl. Microbiol. 19:478-492.

43. Nemeth, J., Paizs, L., and Klement, Z. 1969. The flowerstand blight and seed decay of coriander. Acta Phytopathol. Acad. Sci. Hung. 4:57-62.

44. Parkinson, N., Bryant, R., Bew, J., and Elphinstone, J. 2010. Rapid phylogenetic identification of members of the Pseudomonas syringae species complex using the rpoD locus. Plant Pathol. doi: 10.1111/j.13653059.2010.02366.X

45. Perez-Valder, J. J., Fusikovsky-Zak, L., and Luna-Romera, I. 1990. Etiologia y desarrollo epidemiologico de la bacteriosis del cilantro (Coriandrum sativum). Agro. Ser. Prot. Veg. 1:107-114.

46. Pernezny, K., Raid, R. N., and Jones, J. B. 1997. Bacterial leaf spot of cilantro in Florida. Plant Dis. 81:232.

47. Posada, D. 2008. jModelTest: Phylogenetic model averaging. Mol. Biol. Evol. 25:1253-1256.

48. Rademaker, J. L. W., Louws, F. J., and de Bruijn, F. J. 1998. Characterization of the diversity of ecologically important microbes by rep-PCR genomic fingerprinting. Mol. Microbial. Ecol. Manage. 3.4.3:1-27.

49. Richter, M., and Rosselló-Móra, R. 2009. Shifting the genomic gold standard for the prokaryotic species definition. Proc. Natl. Acad. Sci. USA 106:19126-19131.

50. Ronquist, F., and Huelsenbeck, J. P. 2003. MrBayes3: Bayesian phylogenetic inference under mixed models. Bioinformatics 19:15721574.

51. Sarkar, S. F., and Guttman, D. S. 2004. Evolution of the core genome of Pseudomonas syringae, a highly clonal, endemic plant pathogen. Appl. Environ. Microbiol. 70:1999-2012.

52. Schaad, N. W., Jones, J. B., and Chun, W., eds. 2001. Laboratory Guide for Identification of Plant Pathogenic Bacteria, Third Edition. American Phytopathological Society Press, St. Paul, MN.

53. Sorensen, K. N., Kim, K.-H., and Takemoto, J. Y. 1998. PCR detection of cyclic lipodepsinonapeptide-producing Pseudomonas syringae pv. syringae and similarity of strains. Appl. Environ. Microbiol. 64:226-230.

54. Stackebrandt, E., Frederiksen, W., Garrity, G. M., Grimont, P. A. D., Kämpfer, P., Maiden, M. C. J., Nesme, X., Rosselló-Mora, R., Swings, J., Trüper, H.G., Vauterin, L., Ward, A. C., and Whitman, W. B. 2002. Report of the ad hoc committee for the re-evaluation of the species definition in bacteriology. Int. J. Syst. Evol. Microbiol. 52:1043-1047.

55. Starr, M. P. 1959. Bacteria as plant pathogens. Annu. Rev. Microbiol. 13:211-238.

56. Stead, D. E. 1992. Grouping of plant-pathogenic and some other Pseudomonas spp. by using cellular fatty acid profiles. Int. J. Syst. Bacteriol. 42:281-295.

57. Tamura, K., Dudley, J., Nei, M., and Kumar, S. 2007. MEGA4: Molecular Evolutionary Genetics Analysis (MEGA) software version 4.0. Mol. Biol. Evol. 24:1596-1599.

58. Taylor, J. D., and Dudley, C. L. 1980. Bacterial disease of coriander. Plant Pathol. 29:117-121.

59. Toben, H.-M. and Rudolph, K. 1996. Pseudomonas syringae pv. coriandricola, incitant of bacterial umbel blight and seed decay of coriander (Coriandrum sativum L.) in Germany. J. Phytopathol. 144:169178.

60. Vinatzer, B. A., and Bull, C. T. 2009. The impact of genomic approaches on our understanding of diversity and taxonomy of plant pathogenic bacteria. Pages 37-61 in: Plant Pathogenic Bacteria: Genomics and Molecular Biology. R. W. Jackson, ed. Horizon Scientific Press Hethersett, Norwich, UK.

61. Wayne, L.G., Brenner, D. J., Colwell, R. R., Grimont, P. A. D., Kandler, O., Krichevsky L., Moore, L. H., Moore, W. E. C., Murray, R. G. E., Stackebrandt, E., Starr, M. P., and Trüper, H. G. 1987. Report of the ad hoc committee on reconciliation of approaches to bacterial systematics. Int. J. Syst. Bacteriol. 37:463-464.

62. Weisburg, W. G., Barns, S. M., Pelletier, D. A., and Lane, D. J. 1991. 16S ribosomal DNA amplification for phylogenetic study. J. Bacteriol. 173:697-703.

63. Yan, S., Liu, H., Mohr, T. J., Jenrette, J., Chiodini, R., Zaccardelli, M., Setubal, J. C., and Vinatzer, B. A. 2008. Role of recombination in the evolution of the model plant pathogen Pseudomonas syringae pv. tomato DC3000, a very atypical tomato strain. Appl. Environ. Microbiol. 74:3171-3181.

64. Young, J. M., Park, D.-C., Shearman, H. M., and Frgier, E. 2008. A multilocus sequence analysis of the genus Xanthomonas Syst. Appl. Microbiol. 31:366-377.

65. Yucel, I., Boyd, C., Debnam, Q., and Keen, N. T. 1994. Two different classes of avrD alleles occur in pathovars of Pseudomonas syringae. Mol. Plant-Microbe Interact. 7:131-139.

66. Zhao, Y., Damicone, J. P., and Bender, C. L. 2002. Detection, survival, and sources of inoculum for bacterial diseases of leafy crucifers in Oklahoma. Plant Dis. 86:883-888. 